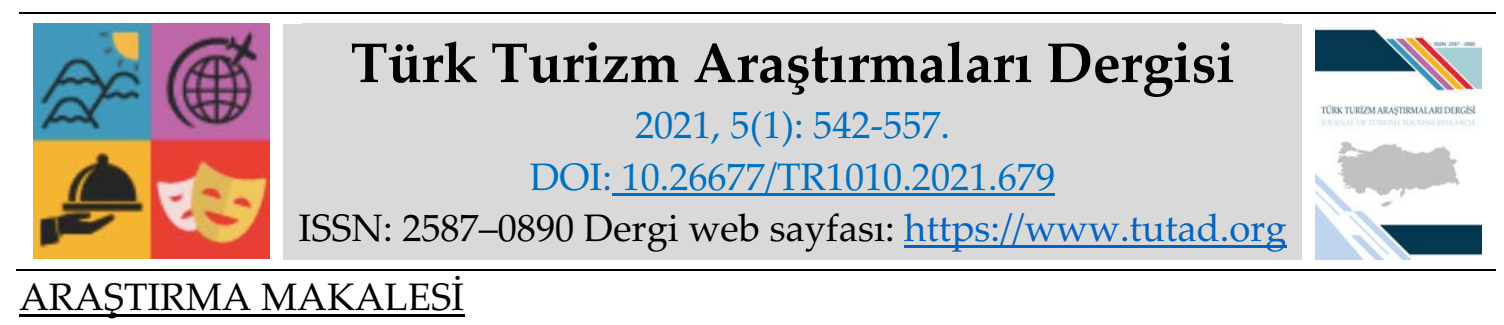

\title{
Akıllı Şehir Endeksi Kapsamında Ankara'ya İlişkin Karşılaştırmalı Bir Analiz
}

Arş. Gör. Dr. Cemal Ersin SİLIK, Ankara Hacı Bayram Veli Üniversitesi, Turizm Fakültesi, Ankara, e-posta:cemal.silik@hbv.edu.tr ORCID: https://orcid.org/0000-0001-8662-4188

Arş. Gör. Dr. Seda ÖZDEMIR AKGÜL, Selçuk Üniversitesi, Turizm Fakültesi, Konya, e-posta: sedaozdemir8@gmail.com

ORCID: https://orcid.org/0000-0003-4482-4119

Öz

Bu çalışmada, Singapur Teknoloji ve Tasarım Üniversitesi (SUTD) ile işbirliği içerisindeki Yönetim Geliştirme Enstitüsü (IMD) tarafından yayınlanan Akıllı Şehir Endeksi (2020) verileri kullanılarak, Ankara ile endeksin ilk on sırasında yer alan şehirlerin (Singapur, Helsinki, Zürih, Auckland, Oslo, Kopenhag, Cenevre, Taipei, Amsterdam, New York) yapı ve teknoloji bakımından karşılaştırılması amaçlanmıştır. Şehirlere ilişkin karşılaştırmalar; sağlık ve güvenlik, ulaşılabilirlik, faaliyetler, firsatlar ve yönetim göstergelerinin ortalama değerleri alınarak yapılmıştır. Çalışmada nitel araştırma yöntemlerinden birisi olan doküman analizi kullanılmıştır. Veriler, QSR NVivo 10 paket programı aracılığı ile analiz edilmiştir. Elde edilen sonuçlar incelendiğinde, Ankara ile endeksin ilk on sırasında yer alan şehirlerin ortalama değerleri arasında yapı ve teknoloji bakımından birtakım farklılıklar belirlenmiştir. Ankara'nın "sağllk ve güvenlik" göstergesi kapsamında, teknolojilerde ilk onda yer alan şehirlere yakın, yapılarda ise daha düşük bir değere sahip olduğu belirlenmiştir. Ankara'nın "ulaşılabilirlik" göstergesi kapsamında, teknolojilerde özellikle online bilet satışlarında ilk onda yer alan şehirlere yakın bir değer aldığı tespit edilmiştir. Ankara'nın "faaliyetler" göstergesi kapsamında ise özellikle yapılarda (kültürel etkinlikler) ilk onda yer alan şehirlerden daha düşük bir değere sahip olduğu belirlenmiştir. Ankara'nın sadece "firsatlar" göstergesi kapsamında hem teknoloji hem de yapılarda ilk onda yer alan şehirlere kıyasla daha yüksek bir değere sahip olduğu anlaşılmıştır. Ayrıca Ankara'nın "yönetim" göstergesi kapsamında, teknolojiler noktasında, ilk onda yer alan şehirlere kıyasla daha yüksek bir değere sahip olduğu tespit edilmiştir.

Anahtar Kelimeler: Akıllı Şehir, Akıllı Şehir Endeksi, Teknoloji, Ankara.

Makale Gönderme Tarihi: 03.01.2021

Makale Kabul Tarihi: 12.03 .2021

Önerilen Atıf:

Silik, C. E. ve Özdemir Akgül, S. (2021). Akıllı Şehir Endeksi Kapsamında Ankara'ya İlişkin Karşılaştırmalı Bir Analiz, Türk Turizm Araştırmaları Dergisi, 5(1): 542-557.

(C) 2021 Türk Turizm Araştırmaları Dergisi. 


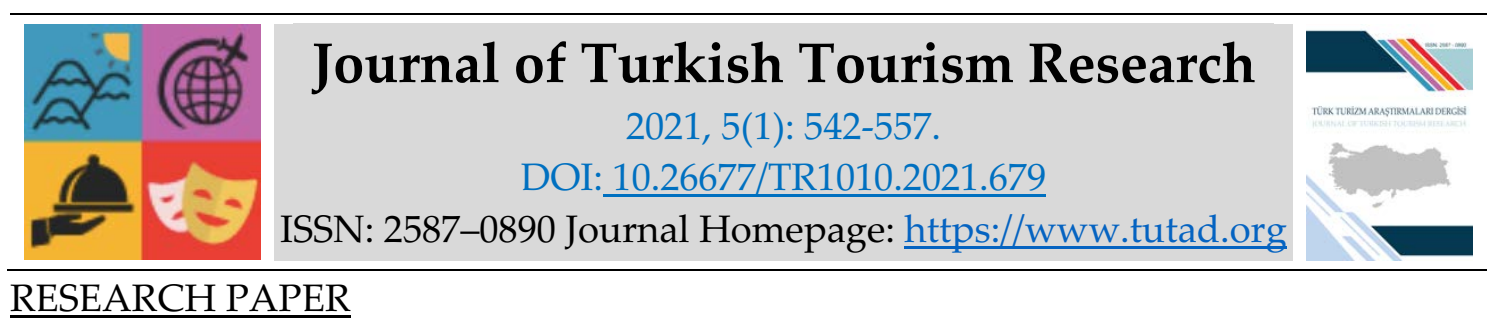

A Comparative Analysis for Ankara in the Context of The Smart City Index

Dr. Cemal Ersin Si̇LiK, Ankara Hacı Bayram Veli University, Faculty of Tourism, Ankara, e-mail: cemal.silik@hbv.edu.tr

ORCID: https://orcid.org/0000-0001-8662-4188

Dr. Seda ÖZDEMIR AKGÜL, Selçuk University, Faculty of Tourism, Konya, e-mail: sedaozdemir8@gmail.com

ORCID: https://orcid.org/0000-0003-4482-4119

\begin{abstract}
In this study, using the Smart City Index (2020) data published by the Institute for Management Development (IMD) in cooperation with the Singapore University for Technology and Design (SUTD), it is aimed to compare Ankara with the top ten cities (Singapur, Helsinki, Zürih, Auckland, Oslo, Kopenhag, Cenevre, Taipei, Amsterdam, New York) in terms of structure and technology. Comparisons regarding cities; average values of health and safety, mobility, activities, opportunities and governance indicators are taken. Document analysis, one of the qualitative research methods, is used in the study. The dates are analyzed through the QSR NVivo 10 package program. When the obtained results are examined, some differences in terms of structure and technology are determined between the average values of Ankara and the cities that are in the top ten of the indexes. Within the scope of the "health and safety" indicator of Ankara, it has been determined that it has a value close to the cities in the top ten in technologies, and lower in structure. Within the scope of the "accessibility" indicator of Ankara, it has been determined that technologies are close to the top ten cities in especially online ticket sales. Ankara has a lower value than the top ten cities, especially in structure (cultural activities) within the scope of the "activities" indicator. Ankara has a higher value compared to the top ten cities in both technology and structure only within the scope of the "opportunities" indicator. In addition, it has been determined that Ankara has a higher value in terms of technologies within the scope of the "management" indicator compared to the cities in the top ten.
\end{abstract}

Keywords: Smart City, Smart City Index, Technology, Ankara.

Received: 03.01.2021

Accepted: 12.03 .2021

Suggested Citation:

Silik, C. E. and Özdemir Akgül, S. (2021). A Comparative Analysis for Ankara in the Context of The Smart City Index, Journal of Turkish Tourism Research, 5(1): 542-557.

(C) 2021 Türk Turizm Araştırmaları Dergisi. 


\section{Gíriş}

Dünyada yaşanan teknolojik gelişmeler ve küresel değişimlerin etkisiyle birlikte destinasyonlarda da birtakım değişiklikler yaşanmaktadır. Bu değişimin başında turizm sektörüne bilgi ve iletişim teknolojilerinin entegre edilmesi gelmektedir. Akıllı turizm kavramı, son dönemlerde turizmin gelişimi için stratejik bir araç olarak önem kazanmış ve farklı ülkelerde yapılan çalışmalar ile genişlemektedir (Gretzel vd., 2015). Akıllı turizm kavramı, beraberinde akıllı turizm destinasyonlarının oluşumuna zemin hazırlamaktadır. Destinasyonlarda akıllı bir turizm platformu oluşturmak destinasyonlar için rekabetçilik açısından önemli bir fırsat sağlamaktadır.

Zaman içerisinde bir destinasyonun rekabet avantajı, doğal kaynakların kullanımının yanında bilgi ve iletişim teknolojilerine uyum ile de sağlanabilmektedir (Wang vd., 2013). Buhalis ve Amaranggana (2015) tarafından yapılan çalı̧̧mada, akıllı turizm destinasyonlarının, bileşenlerinin ve özelliklerinin tanıtımı ile akıllı turizm destinasyonları çerçevesi oluşturulmuştur. Buna göre, akıllı turizm destinasyonlarında turistlerin ve yerel halkın ihtiyaçlarının karşılanması için akıllı şehirlerin unsurları kullanılmaktadır. Bir şehrin küresel ölçekte "akıllı şehir" olarak tanınması, şehirlere yönelik rekabeti, yatırımı ve ilgiyi arttırmada son derece kritik bir öneme sahiptir.

Akıllı turizm destinasyonları, turistler için zevk ve deneyimleri mümkün kılmak amacıyla bilgi teknolojilerini ve yenilikleri kullanan akıllı şehirlerdir. Aslında akıllı şehirler, akıllı turizm destinasyonlarının kurulması için bir merdiven görevi görmektedir (Jasrotia ve Gangotia, 2018). Akıllı şehirlerin kurulması, sadece o bölgede yaşayan vatandaşların yaşamlarını kolaylaştırmakla kalmayıp aynı zamanda sürdürülebilir bir turizm döngüsünün oluşmasına da zemin hazırlamaktadır. Çünkü akıllı şehirlerin merkezinde, akıllı çevre, akıllı ekonomi, akıllı enerji gibi bileşenler de yer almaktadır.

Akıllı şehirlerin önemi, değişen tüketici davranışları sonucunda daha iyi anlaşılabilecektir. Özellikle bu kapsamda sürdürülebilirlik ve teknoloji kavramları ön plana çıkmaktadır. Turizm destinasyonlarının akıllı şehirlere dönüşmesi zamanla zorunluluk haline gelmektedir. Buradan hareketle bu çalışmanın amacı, Ankara şehri ile diğer dünya şehirlerini yapı ve teknoloji bakımından akıllı şehir endeksi çerçevesinde karşılaştırmaktır. Bu kapsamda literatürde yer alan farklı akıllı şehir endeksleri incelenmiştir. Akıllı şehir endeksine yönelik literatürde yapılan araştırmalar sonucunda, Eden Strategy Institute OXD, EasyPark Group, CITY Keys, Bitkom gibi bazı kurum ve kuruluşların akıllı şehir endeksi yayınladıkları tespit edilmiştir. Ayrıca bu kurum ve kuruluşların dışında, Singapur Teknoloji ve Tasarım Üniversitesi (SUTD) ile işbirliği içerisindeki Yönetim Geliştirme Enstitüsü (IMD) tarafından, birtakım göstergeler çerçevesinde, dünya şehirlerinin dijital dönüşümünü ölçmeyi hedefleyen akıllı şehir endeksi yayınlanmaktadır.

Akıllı şehirlere yönelik literatürde yer alan tüm endeksler incelenmiş olup, SUTD-IMD kurum ve kuruluşu tarafından yayınlanan "Akıllı Şehir Endeksi (2020)" tercih edilmiştir. Bu endeksin seçilmesindeki en temel gerekçe endeksin, literatürde en yaygin olarak kullanılan ve küresel ölçekte de en kapsayıcı endeks olmasından kaynaklanmaktadır. 109 tane dünya şehrinin birtakım ölçütlere göre değerlendirildiği endekste, Türkiye'den sadece Ankara şehri yer almaktadır. Türkiye'den sadece Ankara'nın endekste yer almasından dolayı Ankara şehri örneklem olarak seçilmiştir. Bu kapsamda, Ankara ile diğer dünya şehirleri (endekse göre ilk on sırada yer alan şehirler), akıllı şehir endeksi kapsamında karşılaştırılmıştır. Elde edilen sonuçlar, Ankara'nın akıllı şehir olma noktasındaki gelişimini, güçlü ve zayıf noktalarını karşılaştırmalı bir biçimde ortaya koymaktadır. Ayrıca Türkiye'deki diğer büyük şehirlere de kıyaslama yapma imkânı sağlamaktadır. 


\section{KAVRAMSAL ÇERÇEVE}

\section{Akıllı Şehir Kavramı}

Mevcut literatür ve uygulamalar incelendiğinde, "Akıllı Şehir" veya "Akıllı Kent" kavramı üzerine birçok farklı tanım ve uygulamaların yer aldığı görülmektedir. Bu konuda standart bir tanım bulunmamakla birlikte, akıllı şehir veya kentler, kaynakların daha etkin kullanılmasını, kent sakinlerinin yaşantılarını kolaylaştıracak uygulamaların arttırılmasını ve teknolojik hizmetlerin geliştirilerek daha modern bir yaşantının sunulmasını kapsamaktadır (Elvan, 2017: 6). Akıllı şehir kavramı, Akıllı Şehir Endeksi (2020) kapsamında ise, vatandaşları için kentleşmenin faydalarını artırmak ve eksikliklerini azaltmak için teknolojiyi uygulayan kentsel bir ortam olarak tanımlanmaktadır.

Akıllı şehirler, gündelik yaşamı kolaylaştıran teknolojik yenilikler ile birlikte, şehirde yaşayanların şehir ile ilgili alınan kararlara katılmaları için gerekli olan altyapıların oluşturulduğu modern bir tarzı yansıtmaktadır. Bununla birlikte akıllı şehirler, nesnelerin interneti yoluyla anlık veri sağlayan ve bunları bilgiye dönüştürebilen cihazlar üzerine kurulu şehir yapılarını ifade etmektedir (Medeni vd., 2017:243).

Akıllı şehirler ile ilgili yapılan tanımlardaki benzer noktalar, şehirlerin sosyal, ekonomik ve çevresel sürdürülebilirliklerini, akıllı teknolojilerin ve verinin kullanımı yoluyla çözmelerini içermektedir. Akıllı Şehirler Konseyi (Smart City Council) tarafından yapılan tanımlamada ise akıllı şehir, bilgi ve iletişim teknolojilerinin, şehirlerin yaşanabilirliği, çalışılabilirliği ve sürdürülebilirliği için kullanılması anlamına gelmektedir (Benli ve Gezer, 2017).

2019-2022 Ulusal Akıllı Şehirler Stratejisi ve Eylem Planı kapsamında, 17 bileşenden oluşan akıllı şehir yapısı oluşturulmuştur. Buna göre akıllı şehirler; akıllı çevre, akıllı güvenlik, akıllı insan, akıllı yapılar, akıllı ekonomi, akıllı mekân yönetimi, akıllı sağlık, akıllı yönetişim, bilgi teknolojileri, akıllı ulaşım, akıllı enerji, iletişim teknolojileri, bilgi güvenliği, akıllı altyapı, afet ve acil durum yönetimi, coğrafi bilgi sistemleri, yönetişim mekanizması yatırım ve kaynak kullanımı bileşenlerinden meydana gelmektedir. Avrupa Birliği, 28 ülkeyi göz önüne alarak, akıllı şehir olgusunu 6 temel bileşen etrafında toplamaktadır. Bu bileşenler; akıllı yönetişim, akıllı insan, akıllı yaşam, akıllı mobilite, akıllı ekonomi ve akıllı çevredir. Ayrıca Dr. Boyd Cohen tarafından geliştirilen "Akıllı Şehir Çemberi (Smart Cities Wheel)" de Avrupa Birliği tarafından oluşturulan bileşenleri kapsamaktadır (www.webdosya.csb.gov.tr).

Bir kentin akıllı şehir olma sürecinde önde gelen temel konulardan birisi nesnelerin internetidir. Nesnelerin interneti kısaca, nesnelerin birbirleri ile haberleşmesine olanak sağlayan iletişim altyapısı olarak ifade edilmektedir. Bu sayede, kent içerisinde sensörler, cihazlar, iletişim network altyapıları, bulut sistemleri ve yazılımlar aracılı̆̆ıyla hizmetler daha hızlı ve kolay bir biçimde sunulmaktadır (Terzi ve Ocakçı, 2017:12).

\section{Ankara'daki Akıllı Şehir Uygulamaları}

Ankara'daki akıllı şehir uygulama çalışmaları incelendiğinde, Ankara Büyükşehir Belediyesi tarafından başlatılan teknoloji ve bilişime bağlı çalışmalar 2011 yılından itibaren devam etmektedir. Buna bağlı olarak Ankara'da, dijital ödeme, akıllı ulaşım ve bilgi sistemleri gibi çalışmalar mobil uygulamalar ve internet üzerinden hizmete sunulmaktadır. Ayrıca kentsel dönüşüm çalışmaları da bu kapsamda devam etmektedir. Örneğin ulaşım hizmetlerinde, öncelikle kartlı sisteme geçilmiş ve sonrasında akıllı durak, mobil uygulama ve araç içi yolcu bilgilendirme ve kamera sistemleri ile gelişim sağlanmıştır. Ankara'da gerçekleştirilen; önemli park ve meydanlarda Wi-fi ağlarının kurulması, kiosk ve dijital ödeme seçenekleri ile elektrik, su 
ve doğalgaz işlemlerinin gerçekleştirilmesi, uydu sistemlerinin itfaiye vb. gibi araçlarda kullanılarak acil çözüm sunulması, Ankara Katık Atık Projesi ile elektrik enerjisi üretilmesi, doğalgaz ve elektrik ile çalışan otobüs filolarının kurulması, görme engelli vatandaşlar için Braille alfabesi ile yazılmış çevrimiçi kütüphane ve teknoloji eğitimi, sesli kütüphane ile doküman tarama eğitimi verilmesi gibi uygulamalar akıllı kent uygulama örnekleri olarak ifade edilmektedir (Gürsoy, 2019:169).

Literatürde yapılmış bazı çalışmalarda (Gürsoy, 2019; Medeni vd., 2017; Varol, 2017; Duran ve Uygur, 2019), Ankara'daki akıllı şehir uygulamaları yer almaktadır. Ankara Büyükşehir Belediyesi ve ilçe belediyelerinin, bilgi epistemolojisi açısından akıllı şehir düzeyinin incelendiği çalışmada Medeni vd. (2017), e-devlet kapısında Ankara ili belediyeleri ve kurumları tarafından sunulan e-hizmetlerden bahsetmektedir. Belediyelerin ve yerel hizmet kurumu olarak ASKİ'nin sağlamış olduğu hizmetler değerlendirildiğinde, toplam 24 hizmet başlığı yer almaktadır. Yapılan çalışmada, e-devlet kanalı üzerinden en fazla hizmet sağlayan belediyenin Keçiören Belediyesi olduğu anlaşılmaktadır. Mobil cihaz uygulama mağazalarında ise 25 belediye içerisinde sadece 8 tanesinin uygulaması bulunmaktadır. Ayrıca "EGO", "Ankara Büyükşehir Belediyesi" ve "Mavi Masa" nın da uygulaması bulunmaktadır (Medeni vd., 2017:256).

Varol (2017) tarafından yapılan başka bir çalışmada ise, Türkiye'deki akıllı kent çalışmalarının hangi düzeyde olduğu saptanarak, Ankara örneği üzerinden kullanılan uygulamalar incelenmiştir. Çalışma sonuçları incelendiğinde, Büyükşehir Belediyesi'nin ASKİ ve EGO birimlerinin yeni uygulamalar geliştirme noktasında gelişme gösterdikleri anlaşılmaktadır. Ayrıca Altındağ, Yenimahalle ve Sincan Belediyesi Bilgi İşlem Daire'lerinin akıllı uygulamalar konusunda geniş bir vizyona sahip oldukları belirlenmiştir. Akıllı şehir bileşenlerinden akıllı hareketlilik noktasında, sadece EGO Genel Müdürlüğü mobil uygulamalarının aktif bir biçimde kullanıldığı anlaşılmaktadır. Akıllı çevre konusunda ise, ASKİ'nin mobil uygulaması olduğu fakat akıllı sistemlerin yeterince kullanılmadığı tespit edilmiştir (Varol, 2017).

Duran ve Uygur (2019) tarafından yapılan çalışmada, Ankara destinasyonunun sahip olduğu uygulamalar ile akıllı turizm destinasyonu olma özellikleri incelenmiştir. Çalışma kapsamında, Ankara Büyükşehir Belediyesi web sayfasında yer alan "e-Ankara Uygulamaları" bölümündeki akıllı turizme ilişkin mevcut uygulamalar değerlendirilmiştir. Çalışma sonuçları, Ankara'nın akıllı turizm destinasyonu olma konusunda yetersiz kaldığını ortaya koymaktadır (Duran ve Uygur, 2019).

Türkiye Bilişim Vakfı (TBV), MasterCard, Vodafone Türkiye, Intel, İstanbul Teknik Üniversitesi (ITÜ) ve Novusens Akıllı Şehirler Enstitüsü'nün 2016 yılında ortaklaşa yürüttüğü Türkiye Akıllı Şehirler Değerlendirme Raporu'nda, Türkiye'de planlanan akıllı şehir uygulama alanları belirlenmiştir. Özetle raporda, Türkiye'deki belediyelerin planladıkları akıllı şehir uygulama alanları ifade edilmektedir. Buna göre belediyelerin, en çok üzerinde durdukları akıllı şehir uygulama alanları sırasıyla ulaşım, enerji, su, ödeme sistemleri, yapılı çevre, sağlık ve sosyal hizmetler, telekomünikasyon ve kamu güvenliğidir (www.digitaltalks.org).

Akıllı Şehirler Beyaz Bülteni (2019) kapsamında ise Ankara'daki akıllı şehir uygulamaları arasında, Harikalar Diyarı akıllı park projesi, şehir ve trafik kameraları, entegre katı atık yönetim sistemi, Ankara Büyükşehir Belediyesi mobil uygulaması, mezarlık bilgi sistemi mobil uygulaması, telsiz haberleşme sistemi, uydu tabanlı konum belirleme sistemi, elektrik enerji takip sistemi, akıllı ulaşım sistemleri, sıfır atık programı, akıllı toplu ulaşım sistemleri ve akıllı su yönetimi sistemleri yer almaktadır (www.webdosya.csb.gov.tr). 


\section{Akıllı Şehir Endeksi}

Çalışma kapsamında kullanılan Akıllı Şehir Endeksi, Singapur Teknoloji ve Tasarım Üniversitesi (SUTD) ile işbirliği içerisindeki Yönetim Geliştirme Enstitüsü (IMD) tarafından, birtakım göstergeler çerçevesinde, dünya şehirlerinin dijital dönüşümünü ölçmeyi hedefleyen bir endekstir. Endeks, IMD-SUTD tarafından ilk defa iki yıllık bir çalışmanın ardından 2019 yılında 102 tane şehirden elde edilen veriler ile yayınlanmıştır. 2020 yılında ikinci kez yayınlanan endekste ise 109 tane şehre ait veriler yer almaktadır. Bununla beraber, küresel ölçekte akıllı şehirlere yönelik geliştirilen en kapsamlı endekstir.

Akıllı Şehir Endeksi (2020) verilerini elde etmek için 2020 yılının Nisan ve Mayıs aylarında 109 şehirden yüzlerce vatandaş ankete katılmış ve beş temel alanda (sağlık ve güvenlik, ulaşılabilirlik, faaliyetler, fırsatlar ve yönetim) şehirlerinin teknolojik durumları hakkında değerlendirmelerde bulunmuştur. Endeks kapsamında uygulanan metodoloji kısaca şu şekilde özetlenmektedir (Yönetim Geliştirme Enstitüsü, 2021a):

- IMD-SUTD tarafından yayınlanan Akıllı Şehir Endeksi (SCI), şehir sakinlerinin şehirlerindeki mevcut yapılar ve teknoloji uygulamaları ile ilgili konulardaki algılarını değerlendirmektedir.

- Her şehirden 120 yerleşik kişinin değerlendirmeleri ile 109 şehir sıralanmıştır.

- Şehirlerde bulunan yerleşik kişilerden iki sütuna cevap vermeleri istenmiştir. Bunlardan ilki, şehirlerin mevcut altyapısına atıfta bulunan "yapılar" sütunu, diğeri ise, yerleşiklere sunulan teknolojik hizmetleri ve hükümleri açıklayan "teknoloji" sütunudur.

- Her sütun beş temel alanda değerlendirilmiştir. Bu alanlar; sağlık ve güvenlik, ulaşılabilirlik, faaliyetler, fırsatlar ve yönetimdir.

- Şehirler, parçası oldukları ekonominin Birleşmiş Milletler İnsani Gelişme Endeksi (İGE) puanına göre dört gruba ayrılmaktadır. Her İGE grubu içerisindeki şehirlere, aynı gruptaki diğer tüm şehirlerin puanlarına kıyasla, AAA-D aralığında bir puanlama yapilmaktadır.

- Son olarak, 1'den 109'a kadar genel şehir sıralaması yapılmaktadır.

Endekste dört farklı türde puanlama göstergesi bulunmaktadır. Bunlar; akıllı şehir sıralaması, grup, akıllı şehir ve faktör derecelendirmeleridir. Akıllı şehir sıralaması, derecelendirmeye ve bileşenlerine göre ölçülen 109 şehir arasından ilgili şehrin sıralamasıdır. Grup, her şehrin İGE değerlerine göre atandığ 1 dört gruptan birini ifade etmektedir. Akıllı şehir ve faktör derecelendirmeleri ise, her bir şehrin, grup içerisindeki diğer şehirlere ilişkin performansına göre hesaplanmasıdır. IMD Akıllı Şehir Endeksi, bu alanda yapılan en önemli endekslerden birisidir. Vatandaşların, şehirlerini "akıllı" hale getirme çabalarının kapsamını ve etkisini nasıl algıladıklarına odaklanmakta ve "ekonomik ve teknolojik yönler" ile "insani boyutlar" arasında bir denge sağlamaktadır (Yönetim Geliştirme Enstitüsü, 2021b).

\section{LİTERATÜR İNCELEMESI}

Akıllı turizm destinasyonları ile ilgili mevcut araştırmalar (Buhalis ve Amaranggana, 2013; Buhalis ve Amaranggana, 2015; Del Chiappa ve Baggio, 2015; Lamsfus vd., 2015; Boes vd., 2016; Buhalis ve Leung, 2018; Vecchio vd., 2018; Femenia-Serra vd., 2018; Jasrotia ve Gangotia, 2018; Shafiee vd., 2019) ağırlıklı olarak üç alana odaklanmaktadır. Bunlar; (1) akıllı turizm destinasyonlarında kavramsal yaklaşımları oluşturmak ve geliştirmek, (2) akıllı turizm ekosistemi oluşturmak ve (3) akıllı turizm teknolojilerinin akıllı turizm ekosistemine sağladığ1 değeri ortaya koymaktır. 
Literatürde yer alan sınırlı sayıda araştırmada ise (Buhalis ve Amaranggana, 2013; Lamsfus vd., 2015; Boes vd., 2016; Buhalis ve Leung, 2018; Shafiee vd., 2019) akıllı turizm destinasyonları için modeller geliştirilmiştir. İlgili çalışmalarda yer alan akıllı turizm destinasyon modelleri, sürdürülebilirlik, ekosistem, konaklama işletmeleri gibi spesifik çerçevede ele alınmıştır. Bu çalışmaların dışında; Bakıcı vd., 2013; Lamfus vd., 2015; Femenia-Serra ve Neuhofer, 2018; Buhalis ve Leung, 2018; Shafiee vd., 2019; Arenas vd., 2019; Ghorbani vd., 2020 tarafından yürütülen çalışmaların da akıllı turizm destinasyonlarına yönelik katkı sağlayan önemli çalışmalar olduğu belirlenmiştir.

Vecchio ve diğerleri (2018) tarafından yapılan çalışmada, turistlerden elde edilebilen büyük miktarda Sosyal Büyük Verilerin Akıllı Turizm Destinasyonları için değer yaratma sürecini nasıl geliştirebileceğini gösterme amaçlanmıştır. Çok vakalı bir analiz uygulayan çalışma, Güney Avrupa bölgesi ve destinasyonla ilgili bir dizi bölgesel turizm deneyimini araştırmakta ve turizmde Büyük Veri tarafından üretilen değer yaratma modellerini açılamaktadır.

Romao ve Neuts (2017) tarafından yapılan çalışmada ise, doğal ve kültürel özellikler (çevresel boyut), inovasyon yetenekleri ve uzmanlaşma kalıpları (akıllı uzmanlaşma) ile ilgili bölgesel hassas kaynakların, bölgesel sürdürülebilir kalkınmaya (mekânsal sürdürülebilirlik) katkısı analiz edilmiştir. Çalışma sonucunda, bilgi ve iletişim teknolojileri, akıllı turizm deneyimlerini (akıllı gelişim) ve ilgili sektörlerle bağlantılarını (akıllı uzmanlaşma) içeren ürün ve hizmetlere bilgi ve yeniliklerin entegrasyonu yoluyla bu başarılara katkıda bulunabileceği tespit edilmiştir. Literatürde yapılmış akıllı turizm çalışmalarının özeti şeklinde olan Kontogianni ve Alepis (2020) tarafından yapılan çalışmada, akıllı turizm sektöründe en çok kullanılan yaklaşımlar ve temel kavramlar belirlenmiştir. Bu araştırmada sunulan ve tartışılan literatür incelemesi, akıllı turizm ile ilgili 2013-2019 yılları arasında yayınlanmış makalelerin kapsamlı bir çalışmasına dayanmaktadir.

Akıllı turizm destinasyonları ile ilgili yapılmış diğer çalı̧̧malarda (Duran ve Uygur, 2019; Gürsoy, 2019; Varol, 2017; Medeni vd., 2017) ise, destinasyonlardaki akıllı şehir uygulamaları açıklanmaya çalışılmıştır. Ayrıca literatürde yer alan Akıllı Şehirler Beyaz Bülteni, Türkiye Akıllı Şehirler Değerlendirme Raporu ve 2019-2022 Ulusal Akıllı Şehirler Stratejisi ve Eylem Planı gibi bazı rapor ve bültenlerde de akıllı şehirlere yönelik strateji ve değerlendirmeler yer almaktadır.

\section{YÖNTEM}

Çalışmanın amacı doğrultusunda nitel bir araştırma yöntemi olan doküman analizi ile veriler elde edilmiştir. Doküman incelemesi bir analiz biçimi olmasının yanı sıra bir veri toplama yöntemi (Coffey ve Atkinson, 1996) olarak da kullanılmaktadır (O'leary, 2004). Basılı ve elektronik belgelerin sistematik ve titiz bir şekilde analiz edilmesinde bu yöntem kullanılmaktadır (Wach ve Ward, 2013; Bowen, 2009).

Doküman incelemesinde akıllı şehir endeksi ile ilgili hazırlanmış, araştırmaya uygun raporun seçilmesi, gerekli bilgilerin toplanması, tabloların oluşturulması, analiz edilmesi ve yorumlanması aşamaları gerçekleştirilmiştir. 2020 yılında akıllı şehir endeksine yönelik yayınlanan ve doküman inceleme yöntemi ile seçilen raporlar ayrıntılı bir şekilde yazarlar tarafından incelenmiştir. Bu araştırmada, küresel ölçekteki kapsayıcılık ve literatürde yaygın olarak referans alınması bakımından Singapur Teknoloji ve Tasarım Üniversitesi (SUTD) ile işbirliği içerisindeki Yönetim Geliştirme Enstitüsü (IMD) tarafından yayınlanan Akıllı Şehir Endeksi (2020) raporu değerlendirilmiştir.

İlgili raporlarda konu alanları ayrıntılı okunarak ve gruplandırılarak kodlama listeleri yazarlar tarafından ayrı ayrı oluşturulmuştur. Bu süreçte araştırmacılardan metafor ve gerekçelerini liste 
haline getirmeleri ve ilk aşamada araştırmacılar tarafından taslak halinde belirlenen tema/kategoriden birine dahil etmeleri ya da yeni bir tema oluşturmaları istenmiştir. Geçerliliği sağlamak için oluşturulan listeler konuyla ilgili çalışmaları olan üç uzmana sunulmuştur. Uzmanların görüş ve önerileri doğrultusunda gerekli olan düzeltmeler ve değerlendirmeler yapılmıştır.

Toplanan verilerin kodlanmasını kolaylaştırmak için bilgisayar tabanlı nitel analiz programı QSR NVivo 10 kullanılmıştır. Bu program, açıkça ifade edilen önemli kavramların, fikirlerin veya gerekçelerin tanımlanmasına odaklanan endüktif bir kodlama sürecidir (Vaismoradi vd., 2016). Kodlama süreci tamamlandıktan sonra verilerden elde edilen çalışma analizleri yorumlanarak bulgular oluşturulmuştur. İlgili rapor ayrıntılı bir şekilde incelenip veriler elde edilerek, akıllı şehirler arasındaki karşılaştırmalar yapılmıştır. Elde edilen sonuçları daha iyi anlayabilmek için şehirlere yönelik yapılan karşılaştırmalar, tablolar ile birlikte bulgular bölümünde detaylı bir biçimde sunulmuştur.

TR Dizin Dergi Değerlendirme Kriterleri kapsamında yapılan değişiklik ile birlikte, sosyal bilimler dâhil olmak üzere tüm bilim dallarında yapılan çalışmalar için "Etik Kurul Onay" belgesi talep edilmektedir. Fakat bu çalışmada, etik kurul kararı gerektiren (klinik ve deneysel çalışmalar, insandan anket, mülakat, odak grup çalışması vb.) yollar ile veri toplanmadığı ve yöntemde de doküman analizi kullanıldığı için etik kurul iznine gerek duyulmamaktadır.

\section{BULGULAR}

Bu çalışmada, Singapur Teknoloji ve Tasarım Üniversitesi (SUTD) ile işbirliği içerisindeki Yönetim Geliştirme Enstitüsü (IMD) tarafından yayınlanan Akıllı Şehir Endeksi (2020) sonuçlarına göre, 57. sırada bulunan Ankara ile endeksin ilk on sırasında yer alan şehirler (Singapur, Helsinki, Zürih, Auckland, Oslo, Kopenhag, Cenevre, Taipei, Amsterdam, New York), sağlık ve güvenlik, ulaşılabilirlik, faaliyetler, firsatlar ve yönetim göstergelerinin ortalama değerleri ele alınarak yapı ve teknoloji açısından karşılaştırılmıştır. Elde edilen bulgular, göstergeler kapsamında ayrı ayrı sunulmaktadır.

\section{Sağlık ve Güvenlik}

Akıllı Şehir Endeksi (2020) kapsamında, sağlık ve güvenlik göstergesi bakımından elde edilen karşılaştırmalı bulgular Şekil 1'de yer almaktadır.

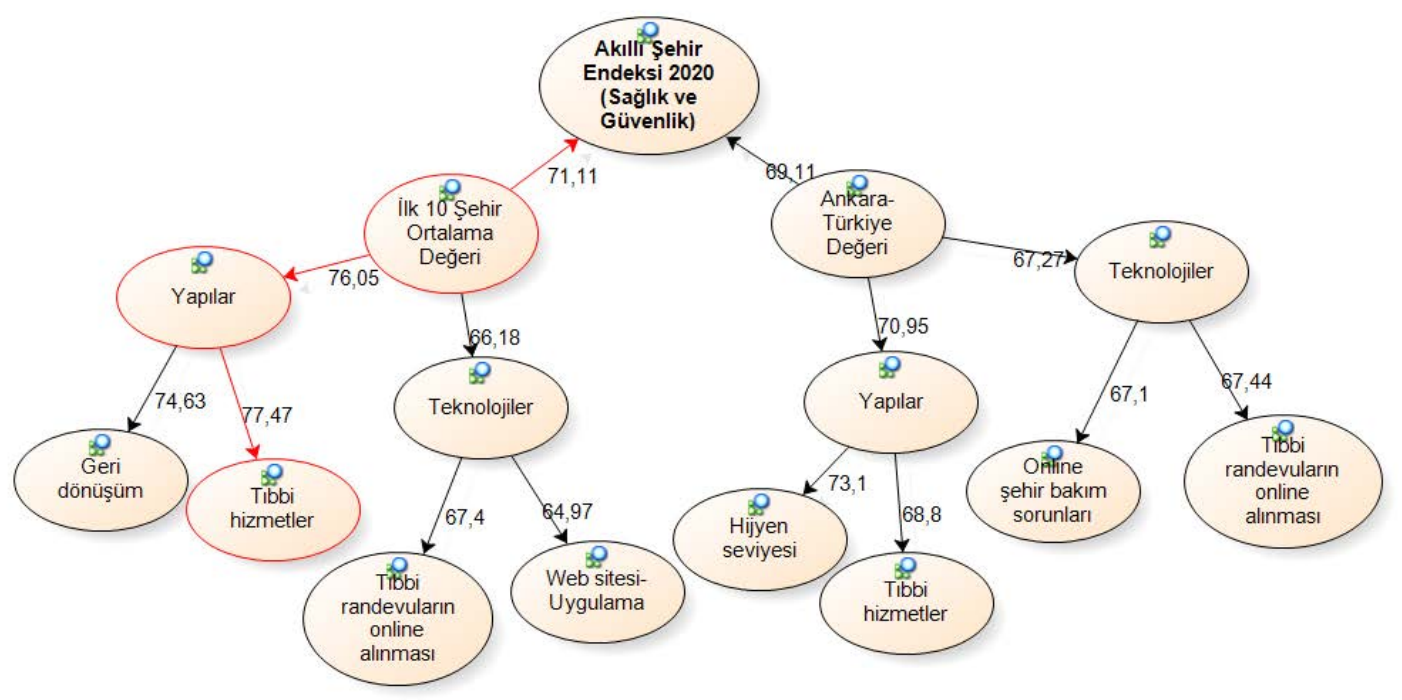

Şekil 1. Sağlık ve Güvenlik Göstergesine Yönelik Elde Edilen Bulgular 
Akıllı Şehir Endeksi (2020) verileri sağlık ve güvenlik açısından değerlendirildiğinde, ilk onda yer alan şehirlerin ortalama değeri yüksek olan yapı ve teknolojileri ile Ankara'nın değerleri farklılık göstermektedir. İlk onda yer alan şehirlerin yapılarında; "geri dönüşüm ve tıbbi hizmetler", teknolojilerinde ise; "tıbbi randevularm online alınması" ve "web sitesi-uygulama" yüksek oran derecesinde bulunmaktadır. Ankara'ya bakıldığında ise yapılarda; "hijyen seviyesi ve tıbbi hizmetler", teknolojilerde ise; "online şehir bakım sorunları" ve "tıbbi randevularm online alınması" bulunmaktadır (Şekil 1). Tibbi hizmetlerde en yüksek değerin, ilk onda yer alan şehirlerin ortalama değerine $(\% 77,47)$ ait olduğu belirlenmiştir. İlk onda yer alan şehirler içerisinde yapılarda "tıbbi hizmetler" (\%87); teknolojilerde de "tıbbi randevularm online alınması" (\%82,9) noktasında en yüksek değere sahip olan şehir Taipei'dir.

\section{Ulaşılabilirlik}

Akıllı Şehir Endeksi (2020) kapsamında, ulaşılabilirlik göstergesi bakımından elde edilen karşılaştırmalı bulgular Şekil 2' de yer almaktadır.

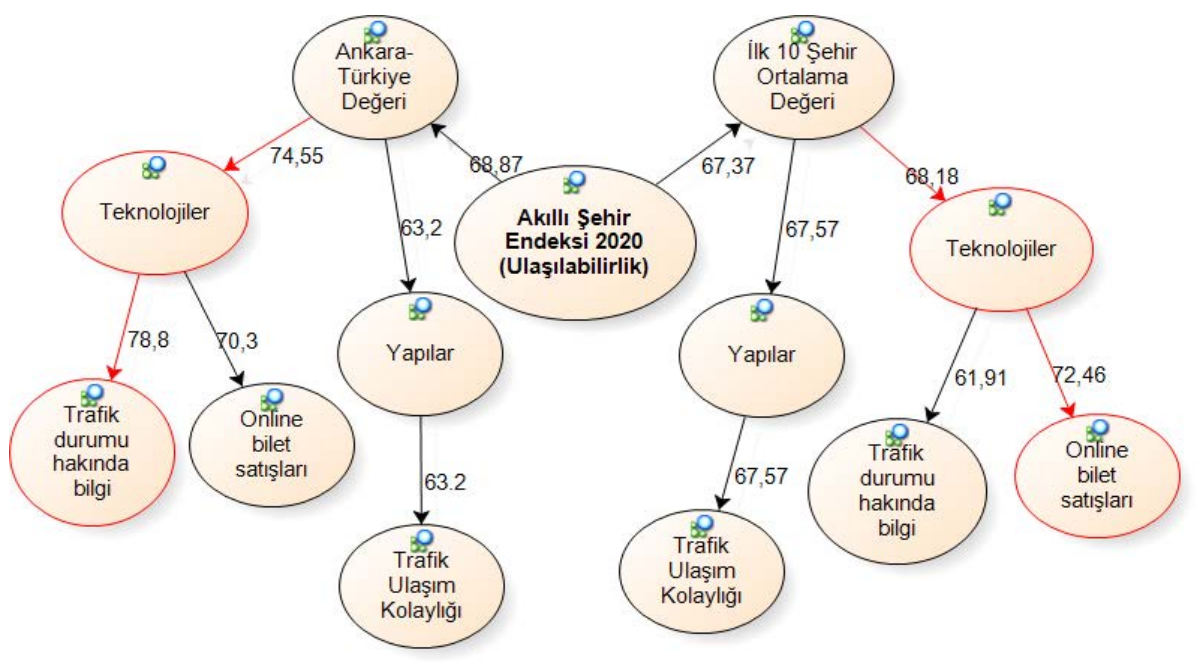

Şekil 2. Ulaşılabilirlik Göstergesine Yönelik Elde Edilen Bulgular

Akıllı Şehir Endeksi (2020) verileri ulaşılabilirlik açısından değerlendirildiğinde, ilk onda yer alan şehirlerin ortalama değeri ve Ankara'nın değerlerinde en yüksek dereceye sahip teknolojiler (trafik durumu hakkında bilgi, online bilet satışları) ve yapılar (trafik ulaşım kolaylığı) Şekil 2'de yer almaktadır. Trafik ulaşım kolaylığında en yüksek değer, ilk onda yer alan şehirlerin ortalama değeridir (\% 67,57). Teknolojiler kısmında ise ilk onda yer alan şehirler, "online bilet satışlarında" yüksek değere $(\% 72,46)$ sahipken, Ankara'nın "trafik durumu hakkında bilgi" konusunda $(\% 78,8)$ yüksek değere sahip olduğu görülmektedir. İlk onda yer alan şehirler içerisinde Helsinki, yapılarda \% 78,1 ve teknolojilerde \% 79,0 ile en üst dereceye sahip şehir konumundadır.

\section{Faaliyetler}

Akıllı Şehir Endeksi (2020) kapsamında, faaliyetler göstergesi bakımından elde edilen karşılaştırmalı bulgular Şekil 3'te yer almaktadır. 


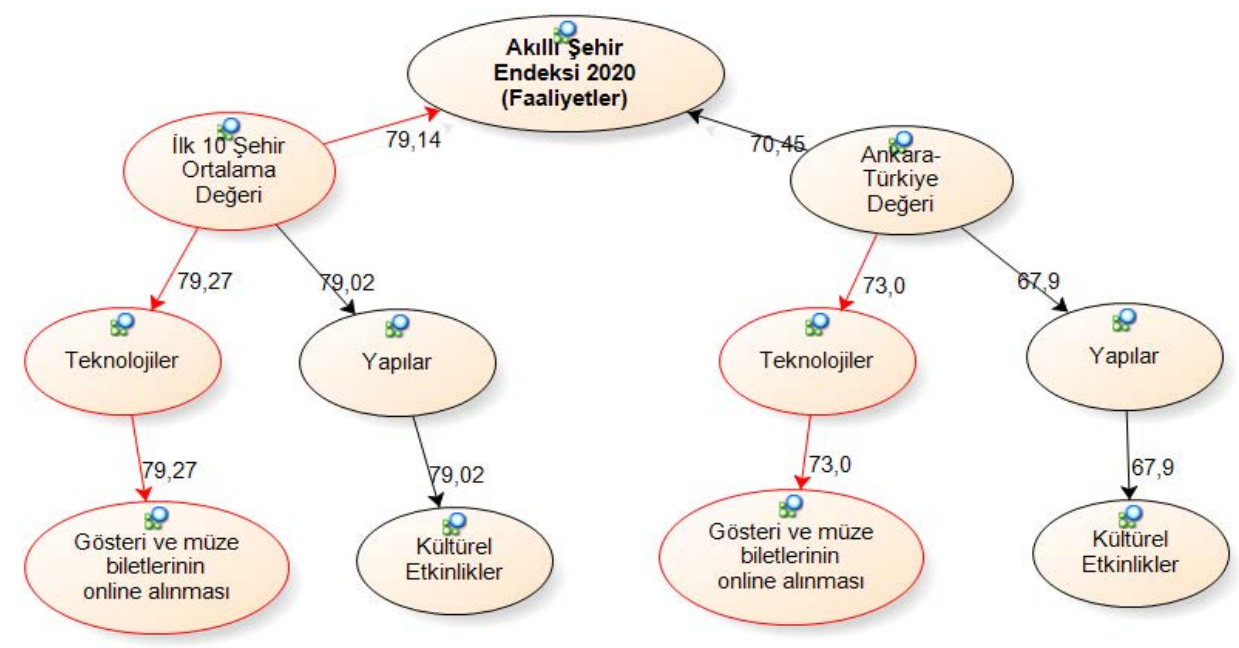

Şekil 3. Faaliyetler Göstergesine Yönelik Elde Edilen Bulgular

Akıllı Şehir Endeksi (2020) verileri faaliyetler bakımından değerlendirildiğinde, teknolojilerde ilk onda yer alan şehirlerin ortalama değerinin yüksek olduğu $(\% 79,14)$ anlaşılmaktadır (Şekil 3). Özellikle "gösteri ve müze biletlerinin online olarak alınması", Ankara şehrine oranla yüksek değerdedir $(\%$ 79,27). Kültürel etkinliklerin yer aldığı yapılarda da, ilk onda yer alan şehirlerin ortalama değeri $(\% 79,2)$, Ankara şehrine kıyasla $(\%$ 67,9) daha yüksek değerdedir. Kültürel etkinliklerde, ilk onda yer alan şehirler içerisinde en yüksek değere sahip olan şehir Cenevre' dir (\% 83,3). Gösteri ve müze biletlerinin online olarak alınmasında ise, en yüksek orana sahip olan şehir Taipei'dir (\% 86,8).

\section{Firsatlar}

Akıllı Şehir Endeksi (2020) kapsamında, fırsatlar göstergesi bakımından elde edilen karşılaştırmalı bulgular Şekil 4'te yer almaktadır.

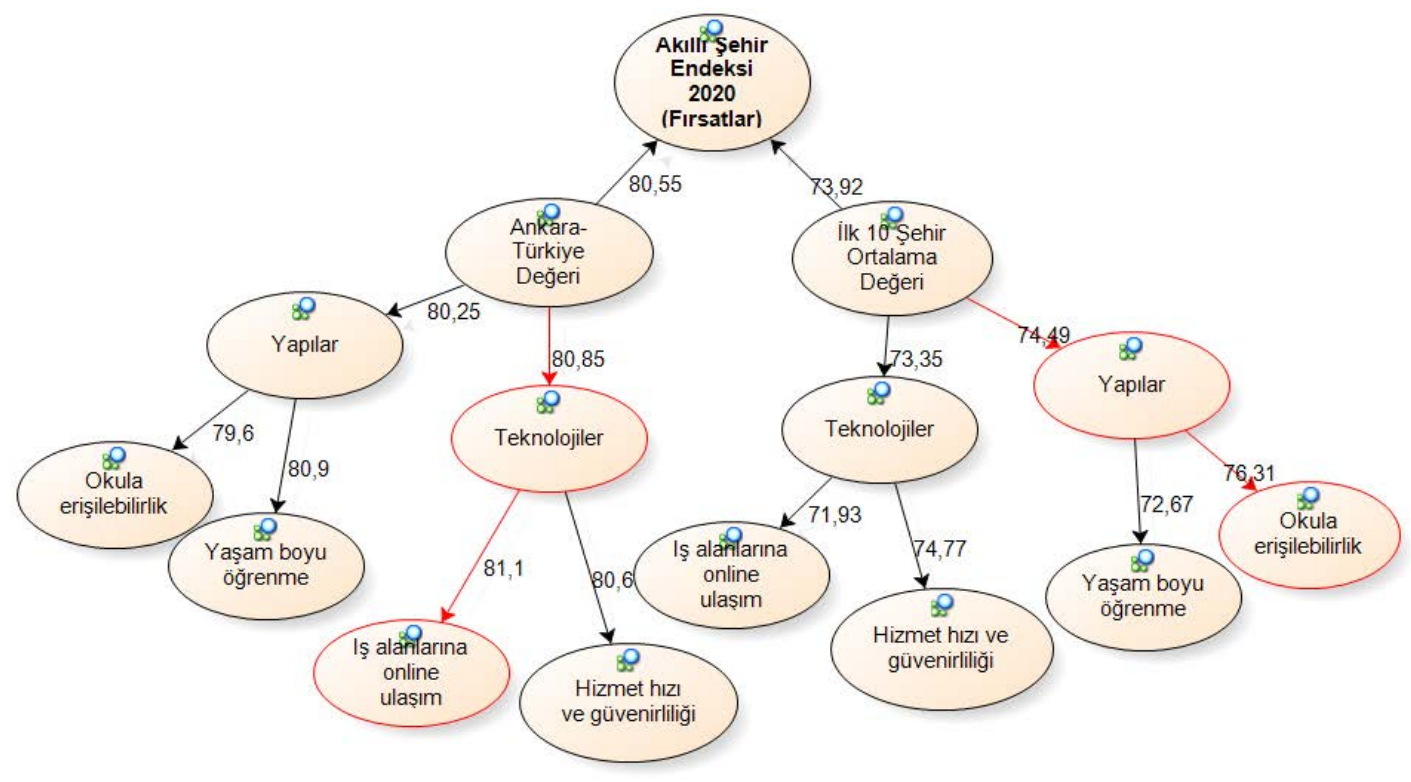

Şekil 4. Fırsatlar Göstergesine Yönelik Elde Edilen Bulgular 
Akıllı Şehir Endeksi (2020) verileri fırsatlar bakımından değerlendirildiğinde, ilk onda yer alan şehirlerin ortalama değeri, en yüksek dereceye sahip yapılar (okula erişilebilirlik) olduğu görülmektedir. Şekil 4'te görüldüğü üzere "okula erişilebilirlik", \% 76,31 oranında bir ortalama değere sahiptir. Ankara'ya bakıldığında ise, "iş alanlarına online ulaşım" noktasında teknolojilerin $(\% 81,1)$ yüksek değere sahip olduğu görülmektedir. İlk onda yer alan şehirler içerisinde Singapur, yapılarda \% 80,9 ve teknolojilerde de \% 81,1 ile en üst dereceye sahip olan şehir konumundadir.

\section{Yönetim}

Akıllı Şehir Endeksi (2020) kapsamında, yönetim göstergesi bakımından elde edilen karşılaştırmalı bulgular Şekil 5'te yer almaktadır.

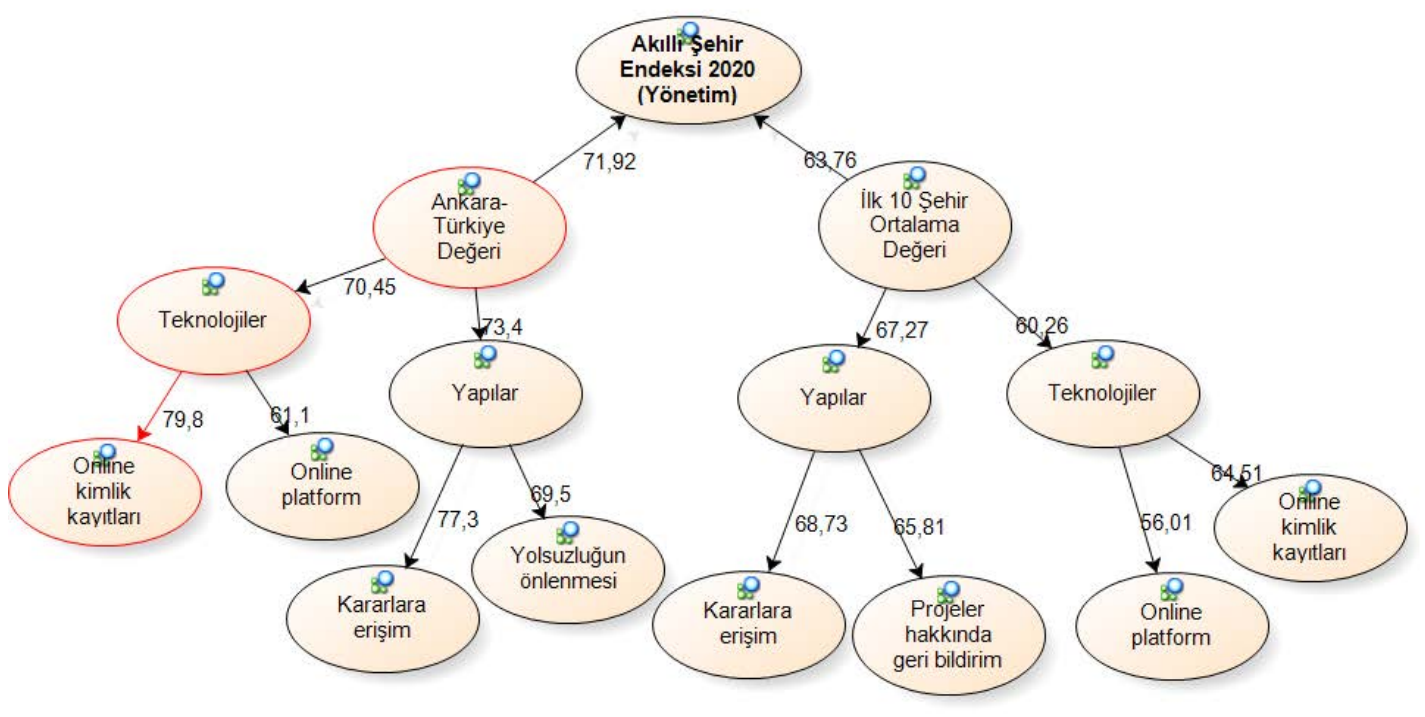

Şekil 5. Yönetim Göstergesine Yönelik Elde Edilen Bulgular

Akıllı Şehir Endeksi (2020) verileri yönetim bakımından değerlendirildiğinde, ilk onda yer alan şehirlerin ortalama değeri yüksek olan yapılar ile Ankara'nın değerleri farklılık göstermektedir. İlk onda yer alan şehirlerin yapılarında "kararlara erişim" ve "projeler hakkında geri bildirim" bulunurken; Ankara'da yapılarda, "kararlara erişim" ve "yolsuzluğun önlenmesi" yer almaktadır (Şekil 5). Teknolojiler açısından değerlendirme yapıldığında ise, ilk onda yer alan şehirlerin ortalaması ile Ankara'nın benzer konularda (online kimlik kartları ve online platform) yüksek değer aldığı görülmektedir. İlk onda yer alan şehirler içerisinde, teknolojilerde "online kimlik kayıtları" konusunda $(\% 79,8)$ ve yapılarda da "kararlara erişim" konusunda $(\% 77,3)$ en yüksek değere sahip olan şehir Singapur'dur.

Akıllı Şehir Endeksi (2020) sıralamasında ilk onda yer alan şehirler ile Ankara, "sağlık ve güvenlik, ulaşılabilirlik, faaliyetler, fırsatlar ve yönetim göstergeleri bakımından karşılaştırılmış ve elde edilen bulgular şekiller ile açıklanmıştır (Şekil 1-5). Elde edilen bulgular incelendiğinde, Ankara'nın endeksin ilk on sırasında yer alan şehirlere kıyasla, "firsatlar" ve "yönetim" göstergeleri kapsamında, hem yapı hem de teknoloji bakımından daha yüksek bir ortalamaya sahip olduğu anlaşılmaktadır. Ankara, "sağllk ve güvenlik" ile "ulaşılabilirlik" göstergeleri kapsamında, endeksin ilk on sırasında yer alan şehirlere kıyasla, yapı bakımından daha düşük, 
teknoloji bakımından daha yüksek bir ortalama değere sahiptir. "Faaliyetler" göstergesi kapsamında ise, gerek yapı gerekse de teknoloji bakımından ilk onda yer alan şehirlere kıyasla daha düşük bir değere sahiptir.

"Sağllk ve güvenlik" göstergesi kapsamında elde edilen bulgular incelendiğinde, Ankara ile endeksin ilk on sırasında yer alan şehirler arasındaki farklılığın, yapı bakımından "tıbbi hizmetler", teknoloji bakımından da "tıbbi randevuların online alınması" konularında meydana geldiği tespit edilmiştir. "Ulaşılabilirlik" göstergesi çerçevesinde bulgular ele alındığında, farklılığın, yapı bakımından "trafik ulaşım kolaylığı", teknoloji bakımından da "online bilet satışları" noktasında gerçekleştiği anlaşılmaktadır. Ankara'nın endeksin ilk on sırasında yer alan şehirlere kıyasla, gerek yapı gerekse de teknoloji bakımından daha düşük değere sahip olduğu göstergenin "faaliyetler" olduğu belirlenmiştir. Ankara ve diğer şehirler arasındaki farklılık, yapı bakımından "kültürel etkinlikler", teknoloji bakımından da "gösteri ve müze biletlerinin online olarak alınması" hususlarında yaşanmaktadır. Bu doğrultuda, Ankara'da özellikle gösteri ve müze biletlerinin online olarak satılması önem arz etmektedir. "Fırsatlar" ve "yönetim" göstergeleri, Ankara'nın, hem yapı hem de teknoloji bakımından endeksin ilk on sırasında yer alan şehirlere kıyasla daha yüksek bir değere sahip olduğu göstergelerdir. Firsatlar göstergesi kapsamında, Ankara ile diğer şehirler arasındaki farklılı̆ıı, yapı bakımından "okula erişilebilirlik", teknoloji bakımından da "iş alanlarına online ulaşım" noktalarında meydana geldiği anlaşılmaktadır. Yönetim göstergesi kapsamında ise temel farklılığın, "online kimlik kayıtları" konusunda yaşandığı tespit edilmiştir. Elde edilen bulgular, Ankara ile endeksin ilk on sırasında yer alan şehirler arasında, ilgili göstergeler doğrultusunda, karşılaştırma yapabilme imkânı sağlamaktadır.

\section{TARTIŞMA, SONUÇ ve ÖNERILLER}

Bilgi, iletişim ve teknoloji alanlarında yaşanan gelişmeler, diğer farklı sektörleri etkilediği gibi turizm sektörünü de etkilemektedir. Bunun yanında, sürdürülebilirlik ve iklim değişikliği gibi konular da son dönemlerde turizm sektörünün odağında yer almaktadır. Ortaya çıan bu durum gerek turizm sektöründeki işletmelerin gerekse de turizm destinasyonlarının teknoloji ve sürdürülebilirlik noktasında uyum stratejileri geliştirmelerini gerekli kılmaktadır. Bu noktada, turizm destinasyonlarında akıllı teknolojilerin kullanılması, şehirlerin "akıllı şehir" olarak tanıtılması önem arz etmektedir. Akıllı şehirlerin sayılarının artması, akıllı şehirlere yönelik endeks çalışmalarının yapılması konunun önemini ortaya koymaktadır. Buradan hareketle bu çalışmada, Akıllı Şehir Endeksi (2020) verileri kullanılarak, birtakım göstergelere göre Ankara'nın diğer şehirler karşısındaki durumunu ortaya koymak amaçlanmıştır. Akıllı Şehir Endeksi, Singapur Teknoloji ve Tasarım Üniversitesi (SUTD) ile işbirliği içerisindeki Yönetim Geliştirme Enstitüsü (IMD) tarafından, birtakım göstergeler çerçevesinde, dünya şehirlerinin dijital dönüşümünü ölçmeyi hedefleyen bir endekstir. 2020 yılında ikinci kez yayınlanan endekste, 109 tane şehre ait veriler yer almaktadır. Çalışmada, Akıllı Şehir Endeksi (2020) verileri kullanılarak, Ankara ile endeksin ilk on sırasında yer alan şehirlerin (Singapur, Helsinki, Zürih, Auckland, Oslo, Kopenhag, Cenevre, Taipei, Amsterdam, New York) "sağllk ve güvenlik, ulaşılabilirlik, faaliyetler, firsatlar ve yönetim" göstergelerinin ortalama değerleri alınarak yapı ve teknoloji bakımından karşılaştırılmıştır.

Elde edilen sonuçlar "sağllk ve güvenlik" açısından değerlendirildiğinde, ilk on şehrin ortalamasında, yapılarda "tıbbi hizmetler" in, teknolojilerde ise "tıbbi randevuların online alınması" nın yüksek değere sahip olduğu tespit edilmiştir. Ankara'nın ise "tıbbi hizmetler" ve "tıbbi randevuların online alınması" noktasında ilk onda yer alan şehirlerin ortalamasına göre daha düşük değere sahip olduğu görülmektedir. Ankara'nın başkent olması, özellikle sağlık kaleminden 
Türkiye'nin ekonomide önemli gelir elde etmesi açısından düşünüldügünnde gelecek yıllarda küresel ekonomiye katkı sağlayacağı düşünülmektedir. Bölgesel büyümede bilgi ve iletişim teknolojileri, bir destinasyonun rekabet tarzını değiştirmektedir (Bakıcı vd., 2013; Wang vd., 2013). İTÜ Vakfı Yayınları tarafından hazırlanan Akıllı Şehirler (2017) çalışmasında, Endüstri 4.0 süreciyle yaşanan gelişmelerin, dijital dönüşümün sağlık alanında değişimlerin yaşanmasına sebep olacağı düşünülmektedir. Bu doğrultuda, tıbbi hizmetlerin son derece gelişmiş teknolojilerle verilmesi, tıbbi randevuların ise var olan online uygulamalar geliştirilerek yapılması gerekmektedir. Güvenlik açısından değerlendirildiğinde ise, vatandaşların ve şehrin sağlık ve güvenliğini kapsayan bu boyutta asayiş, arama-kurtarma, acil ilkyardım hizmetleri bulunmaktadır. Örneğin bir şehirde suç unsurunu azaltmak için yönetim binalarına güvenlik kameraları konulmaktadır.

Çalışma sonuçları "ulaşılabilirlik" boyutunda değerlendirildiğinde, ilk onda yer alan şehirlerin ortalamasında, yapılarda "trafik ulaşım kolaylı̆̆ı", teknolojilerde ise "online bilet satışları" yüksek değere sahip olmuştur. Ankara'nın ise, yapılarda benzer şekilde "trafik ulaşım kolaylı̆̆ı", teknolojilerde ise "trafik durumu hakkında bilgi" noktasında yüksek değere sahip olduğu belirlenmiştir. Büyük metropollerde nüfus sayısına bağlı olarak trafik yoğunluğu bulunmaktadır. Ankara' da çeşitli mobil uygulamalar aracılığıyla trafik durumu hakkında vatandaşlar bilgi alarak hem seyahat süresini kısaltmakta hem de stres altında kalmadan verimli bir yolculuk yapabilmektedir. Giffinger vd., (2007)'nin çalışmasına göre akıllı şehir, yerel ve uluslararası ulaşıma erişim sağlayarak ulaşım sistemlerindeki verimliliği artırmayı, zamandan ve maliyetlerden tasarruf etmeyi ve $\mathrm{CO}^{2}$ emisyonlarını azaltmayı amaçlamaktadır. Bu noktada Ankara'da, otobüs ve metro gibi ulaşım araçları için "Ankarakart" kullanılmaktadır. Bu karta kredi kartı kullanılarak online yükleme yapabilmenin yanı sıra temassız kredi kartı sahipleri, otobüs ve metro istasyonlarında Ankarakart'a ihtiyaç duymadan belli ücret karşılığında geçiş yapabilmektedir. Gürsoy (2019)'da yapmış olduğu çalışmada Ankara'da, dijital ödeme, akıllı ulaşım ve bilgi sistemleri gibi çalışmalar mobil uygulamalar ve internet üzerinden hizmete sunulduğunu ifade etmektedir. Örneğin ulaşım hizmetlerinde, öncelikle kartlı sisteme geçilmiş ve sonrasında akıllı durak, mobil uygulama ve araç içi yolcu bilgilendirme ve kamera sistemleri ile gelişim sağlanmıştır. Akıllı Şehir Endeksi (2020)'nde ilk onda yer alan şehirler ile kıyaslandığında, Ankara'nın daha üst sıralarda yer alabilmesi için, teknolojilerde çeşitli "mobil uygulamalar", "karekod uygulamaları"; yapılarda ise, trafik ulaşım kolaylığı için tramvay gibi "raylı sistemlerin kurulması" nın yanı sıra mevcut metronun da havalimanı gibi farklı güzergâhlarda geliştirilmesi önerilmektedir.

Akıllı Şehir Endeksi (2020) verileri "yönetim" açısından değerlendirildiğinde, teknolojilerde ilk onda yer alan şehirlerin ortalaması ile Ankara'nın "online kimlik kartları" ve "online platform" da yüksek değer aldığı görülmektedir. Yapılarda ise, endekste ilk onda yer alan şehirler ile Ankara arasında herhangi bir farklılık bulunmaktadır. İlk onda yer alan şehirlerde "kararlara erişim" ve "projeler hakkında geri bildirim" bulunurken, Ankara'da, "kararlara erişim" ve "yolsuzluğun önlenmesi" yer almaktadır. Medeni vd., (2017)'ne göre şehirde yaşayanların, şehir ile ilgili alınan kararlara katılmaları için gerekli olan altyapıların oluşturulduğu modern bir tarz bulunmaktadır. Bu bakış açısıyla, yerel halkın kararlara katılımı, yönetimin halka karşı şeffaf olması, o bölgenin kalkınmasında oldukça büyük öneme sahiptir. Abdioğlu (2007), Çelik ve Topsakal (2017) tarafından yapılan çalışmalarda, hükümetin yerel halkla etkileşim kurarak karar almasının; şeffaflık, hesap verebilirlik, adillik ve sorumluluk ilkeleri doğrultusunda yer aldığı ifade edilmektedir.

Endeks verileri "faaliyetler" açısından değerlendirildiğinde, ilk onda yer alan şehirler ile Ankara'nın aynı boyutlarda yüksek değerlere sahip olduğu anlaşılmaktadır. Ankara'ya kıyasla ilk onda yer alan şehirler teknolojide, "gösteri ve müze biletlerinin online olarak alınması" noktasında, 
yapılarda ise, "kültürel etkinlikler" noktasında yüksek orana sahiptir. Ankara'nın, kültürel etkinliklerde yüksek değerlere ulaşabilmesinde, yapılan etkinlikler ile ilgili bireylere doğru bilgi akışı sağlanması gerekmektedir. Bu doğrultuda, çeşitli etkinliklerin duyurulduğu bir online platform oluşturulabilir. Örneğin otobüs ya da metro gibi toplu ulaşım araçlarını kullanan bireylere ekranlardan gidilen güzergahta yapılan etkinliklerle ilgili bilgi akışı sağlanabilir.

Akıllı Şehir Endeksi (2020) verileri "firsatlar" bakımından değerlendirildiğinde ise, ilk onda yer alan şehirlerin ortalama değerlerinin "okula erişilebilirlik" noktasında en yüksek değere sahip olduğu tespit edilmiştir. Ankara'nın, yapılarda, "okula erişilebilirlik" ve "yaşam boyu öğrenme" noktalarında; teknolojilerde ise, "iş alanlarına online ulaşım" ve "hizmet hızı ve güvenliğĭ" noktalarında, ilk onda yer alan şehirlerin ortalama değerlerine göre yüksek değere sahip olduğu belirlenmiştir. Ankara'nın, akıllı şehir endeksleri kapsamında, daha üst sıralarda yer alabilmesi için ilgili tüm boyutlarda gelişme göstermesi gerekmektedir. Ankara'nın, endeksin ilk on sırasında yer alan diğer dünya şehirleri ile kıyaslandığında, gerek yapı gerekse de teknoloji bakımından gelişme göstermesi gerekmektedir. Çünkü teknoloji ve sürdürülebilirlik kapsamında yaşanan gelişmelerin, akıllı şehirlerin sayısını arttıracağı düşünülmektedir.

Pratik düzeyde bu çalışma, Ankara ile diğer dünya şehirleri arasındaki farklılıkları ortaya koyarak, akıllı şehir projelerine bilgi sağlamakta ve bu bilgilerin çeşitli kurum ve kuruluşlara rehberlik etmesini sağlamaktadır. Teorik düzeyde ise, akıllı şehir endeksi kapsamında kısıtlı sayıda çalışmaların bulunmasından dolayı literatüre katkı sağlaması ve benzer çalışmalara da rehberlik etmesi bakımından önem arz etmektedir. Çalışma kapsamında, Singapur Teknoloji ve Tasarım Üniversitesi (SUTD) ile işbirliği içerisindeki Yönetim Geliştirme Enstitüsü (IMD) tarafından yayınlanan Akıllı Şehir Endeksi (2020)'nin kullanılması çalışmanın sınırlılı̆̆ını ortaya koymaktadır. Bu sebeple, akıllı şehirlere yönelik literatürde yer alan farklı endekslerin kullanılması, Ankara dışında Türkiye'deki farklı metropollerin karşılaştırılması, bölgeler arası karşılaştırmaların yapılması gelecek araştırmacılar için önerilen konular arasında yer almaktadır.

\section{KAYNAKÇA}

Abdioğlu, H. (2007). Yönetişim İlkelerinin Uygulanmasında Kamu Denetçiliği (ombudsmanlık) Kurumu ve Avrupa Birliği Sürecinde Türkiye Açısından Önemi, İstanbul Ticaret Üniversitesi Sosyal Bilimler Dergisi, 6(11): 79-102.

Akıllı Şehirler (2017). https://www.ituvakif.org.tr/dergi/sayi_77.pdf, [Erişim Tarihi: 10.01.2020].

Arenas, A. E., Goh, J. M. and Urueña, A. (2019). How Does IT Affect Design Centricity Approaches: Evidence From Spain's Smart Tourism Ecosystem, International Journal of Information Management, 45, 149-162.

Bakıcı, T., Almirall, E., Wareham, J. (2013). A Smart City Initiative: The Case of Barcelona, Journal of the Knowledge Economy, 4(2): 135-148.

Benli, B. ve Gezer, M. (2017). Akıllı Şehirlere Dönüşüm Yolunda Türkiye, İTü Vakfı Dergisi, 77: 28-31.

Boes, K., Buhalis, D. and Inversini, A. (2016). Smart Tourism Destinations: Ecosystems for Tourism Destination Competitiveness, International Journal of Tourism Cities, 2(2): 108-124.

Bowen, G. A. (2009). Document Analysis as A Qualitative Research Method, Qualitative Research Journal, 9(2): 27-40.

Buhalis, D. and Amaranggana, A. (2013). Smart Tourism Destinations, In: Information and Communication Technologies in Tourism 2014, Springer, Cham. 
Buhalis, D. and Amaranggana, A. (2015). Smart Tourism Destinations Enhancing Tourism Experience Through Personalisation of Services. Switzerland: Springer International Publishing.

Buhalis, D. and Leung, R. (2018). Smart Hospitality-Interconnectivity and Interoperability Towards an Ecosystem, International Journal of Hospitality Management, 71: 41-50.

Coffey, A. and Atkinson, P. (1996). Making Sense of Qualitative Data: Complementary Research Strategies. Newbury Park, CA: Sage Publications.

Çelik, P. ve Topsakal, Y. (2017). Akıllı Turizm Destinasyonları: Antalya Destinasyonunun Akıllı Turizm Uygulamalarının İncelenmesi, Seyahat ve Otel İşletmeciliği Dergisi, 14(3): 149-166.

Del Chiappa, G. and Baggio, R. (2015). Knowledge Transfer in Smart Tourism Destinations: Analyzing the Effects of a Network Structure, Journal of Destination Marketing \& Management, 4(3): 145-150.

Duran, G. ve Uygur, S. M. (2019). Akıllı Turizm Destinasyonları Kapsamında Ankara'nın Akıllı Turizm Uygulamalarına Yönelik Bir Araştırma. 3. Uluslararası Turizmin Geleceği Kongresi: İnovasyon, Girişimcilik ve Sürdürebilirlik Kongresi (FUTOURISM 2019), 26-28 Eylül 2019, Mersin, Türkiye.

Elvan, L. (2017). Akıllı Şehirler: Lüks Değil İhtiyaç, İTü Vakfı Dergisi, 77: 6-9.

Femenia-Serra, F. and Neuhofer, B. (2018). Smart Tourism Experiences: Conceptualisation, Key Dimensions and Research Agenda, Journal of Regional Research, 42: 129-150.

Femenia-Serra, F., Neuhofer, B. and Ivars-Baidal, J. A. (2018). Towards A Conceptualisation of Smart Tourists and Their Role Within the Smart Destination Scenario, The Service Industries Journal, 39: 109-133.

Ghorbani, A., Danaei, A., Zargar, S. M. and Hematian, H. (2020). Designing of Smart Tourism Organization (Sto) For Tourism Management: A Case Study of Tourism Organizations of South Khorasan Province, İran, Heliyon, 6: 1-9.

Giffinger, R. (2007). Smart Cities Ranking of European Medium-Sized Cities. Vienna: Vienna University of Technology.

Gretzel, U., Sigala, M., Xiang, Z. and Koo, C. (2015). Smart Tourism: Foundations and Developments, Electronic Markets, 25(3): 179-188.

Gürsoy, O. (2019). Akıllı Kent Yaklaşımı ve Türkiye'deki Büyükşehirler İçin Uygulama İmkânları, Yayınlanmış Yüksek Lisans Tezi, Hacettepe Üniversitesi, Ankara.

https://webdosya.csb.gov.tr/db/cbs/akillisehirler/, [Erişim Tarihi: 05.01.2021].

https://www.digitaltalks.org/2016/03/01/sehrin-akilli-hali/, [Erişim Tarihi: 05.01.2020].

Jasrotia, A. and Gangotia, A. (2018). Smart Cities to Smart Tourism Destinations: A Review Paper, Journal of Tourism Intelligence and Smartness, 1(1): 47-56.

Kontogianni, A. and Alepis, E. (2020). Smart Tourism: State of The Art and Literature Review for The Last Six Years, Array, 6: 1-12.

Lamsfus, C., Martin, D., Alzua-Sorzabal, A., Torres-Manzanera, E. (2015). Smart Tourism Destinations: An Extended Conception of Smart Cities Focusing on Human Mobility, (Eds.) Tussyadiah, I. and Inversini, A., In: Information and Communication Technologies in Tourism 2015, Switzerland: Springer International Publishing. 
Medeni, İ. T., Medeni, T. D. ve Asunakutlu, T. (2017). Akıllı Şehir Olarak Ankara: E-Devlet Hizmetleri Özelinde Ankara Belediyelerinin Değerlendirilmesi, (Editör) Kar, M. ve Sarıkaya, M. A.: Şehir Ekonomisi Ankara Şehir Araştırmaları içinde, Ankara: Ankara Büyükşehir Belediyesi Basın Yayın Dairesi Başkanlığı Yayınları.

O'leary, Z. (2004). The Essential Guide to Doing Research. London: Sage Publications.

Romao, J. and Neuts, B. (2017). Territorial Capital, Smart Tourism Specialization and Sustainable Regional Development: Experiences from Europe, Habitat International, 68: 64-74.

Shafiee, S., Ghatari, A. R., Hasanzadeh, A. and Jahanyan, S. (2019). Developing A Model for Sustainable Smart Tourism Destinations: A Systematic Review, Tourism Management Perspectives, 31: 287-300.

Terzi, F. ve Ocakçı, M. (2017). Kentlerin Geleceği: Akıllı Kentler, İTÜ Vakfı Dergisi, 77: 10-13.

Vaismoradi, M., Jones, J., Turunen, H. and Snelgrove, S. (2016). Theme Development in Qualitative Content Analysis and Thematic Analysis, Journal of Nursing Education and Practice, 6(5): 100-110.

Varol, Ç. (2017). Sürdürülebilir Gelişmede Akıllı Kent Yaklaşımı: Ankara'daki Belediyelerin Uygulamaları, Çă̆daş Yerel Yönetimler, 26(1): 43-58.

Vecchio, P. D., Mele, G., Ndou, V. and Secundo, G. (2018). Creating Value from Social Big Data: Implications for Smart Tourism Destinations, Information Processing and Management, 54: 847-860.

Wach, E. ve Ward, R. (2013). Nitel Belge Analizi Hakkında Bilgi Edinme. [Online] https://opendocs.ids.ac.uk/opendocs/handle/20.500.12413/2989, [Erişim Tarihi: 25.12.2020].

Wang, D., Li, X. and Li, Y. (2013). China's "Smart Tourism Destination" Initiative: A Taste of The Service-Dominant Logic, Journal of Destination Marketing \& Management, 2: 59-61.

Yönetim Geliştirme Enstitüsü (2021a). https://www.imd.org/smart-city-observatory/smart-cityindex/, [Erişim Tarihi: 05.01.2021].

Yönetim Geliştirme Enstitüsü (2021b). https://www.imd.org/research-knowledge/reports/imdsmart-city-index-2019/, [Erişim Tarihi: 05.01.2021]. 